\title{
ANALISIS KESESUAIAN PENGGUNAAN BAHAN AJAR BAHASA MANDARIN SEKOLAH MENENGAH UMUM DENGAN KETETAPAN BADAN STANDAR NASIONAL PENDIDIKAN
}

\author{
Sri Haryanti \\ Chinese Department, Faculty of Humanities, BINUS University \\ Jl. Kemanggisan Ilir III No 45, Kemanggisan-Palmerah, Jakarta Barat 11480 \\ thincele@yahoo.com
}

\begin{abstract}
Teaching material is the important component in teaching and learning process, therefore, choosing the correct one will make easy the achievement of the learning objective. The Education National Standard Foundation (Badan Standar Nasional Pendidikan) arranges the basic competence standard which will be achieved in learning process as well as the topics which must be covered in the given teaching material. Every education stage has different material, and it is also different for the learner in different study program who will have different teaching material which is in accordance with the field of study and the expected goal. To achieve the good learning objective, the teacher has right to choose the textbook which is going to be used in the learning activities. However, there are also some schools decide to cooperate with other course institutions in running the Mandarin Language teaching and learning activities. The limitation of the availabality of Mandarin textbook which uses Indonesian language gives certain difficulty to the learners not only for the learning activity but also for the process of transferring the knowledge. The writer tries to describe the teaching material used by Senior High School and to see whether that textbook has fulfilled basic competence standard criteria which is going to be achieved by using discussion method with Senior High Schools teachers. It also tries to enlighten the material inside the textbook which is used by the teacher. The writer hopes there will be Mandarin Language Textbook which meets the basic competence standard which is able to support the learners in order to achieve the objective of the Mandarin Language learning process in Senior High School.
\end{abstract}

Keywords: teaching material, basic competence standard, the choosing of textbook, Senior High School

\begin{abstract}
ABSTRAK
Bahan ajar merupakan komponen penting dalam proses pembelajaran oleh karena itu pemilihan bahan ajar yang tepat akan memudahkan tercapainya tujuan pembelajaran. Badan Standar Nasional Pendidikan (BSNP) mengatur standar kompetensi dasar yang akan dicapai dalam proses pembelajaran serta materi ajar apa saja yang harus tercakup didalam bahan ajar tersebut. Setiap jenjang pendidikan memiliki materi yang berbeda, begitu juga dengan program studi si pembelajar akan memiliki materi pembelajaran yang berbeda pula sesuai dengan tujuan yang akan dicapai. Guna mencapai tujuan pembelajaran yang baik, guru berhak memilih buku ajar yang akan digunakan, terkadang pihak sekolah yang memutuskan buku ajar yang akan digunakan dalam proses pembelajaran tersebut. Bahkan ada juga pihak sekolah yang bekerjasama dengan lembaga kursus dalam penyelenggaraan pembelajaran Bahasa Mandarin menyerahkan sepenuhnya buku ajar kepada pihak kursus. Masih sedikitnya buku ajar yang menggunakan bahasa Indonesia sangat menyulitkan siswa pembelajar dan proses transfer ilmu. Penulis berusaha menjabarkan bahan ajar yang digunakan di Sekolah Menengah Umum dan melihat apakah buku ajar tersebut sudah memenuhi kriteria standar kompetensi dasar yang hendak dicapai dengan menggunakan metode diskusi dengan guru-guru Sekolah Menengah Umum serta mencoba menguraikan materi yang terdapat didalam buku ajar yang mereka gunakan. Penulis berharap kelak akan adanya buku-buku pengajaran Bahasa Mandarin yang memenuhi standar kompetensi dasar yang sesuai dengan kondisi pembelajar guna tercapainya tujuan pembelajaran Bahasa Mandarin pada Sekolah Menengah Umum.
\end{abstract}

Kata Kunci: materi ajar, standar kompetensi dasar, pemilihan buku ajar, Sekolah Menengah Umum 


\section{PENDAHULUAN}

Pengajaran Bahasa Mandarin pada tingkat Sekolah Menengah Umum dewasa ini sudah tidak lagi menjadi sebuah mata pelajaran yang diberikan secara ekstrakurikuler tetapi sudah menjadi sebuah mata pelajaran intrakurikuler. Pembelajaran Bahasa Mandarin diberikan secara bertahap yang dimulai pada kelas X dan berlanjut hingga ke kelas XII.

Untuk memenuhi tujuan pembelajaran, maka dibutuhkan bahan ajar yang mampu memenuhi standar serta tujuan pembelajaran Bahasa Mandarin itu sendiri. Bahan ajar adalah segala bentuk bahan, informasi, alat dan teks yang digunakan untuk membantu guru/instruktor dalam melaksanakan kegiatan belajar mengajar. Bahan yang dimaksud bisa berupa tertulis maupun bahan yang tidak tertulis. Bahan ajar atau materi kurikulum adalah isi atau muatan kurikulum yang harus dipahami oleh siswa dalam upaya mencapai tujuan kurikulum. (Majid, 2007: 174).

Oleh karenanya pemilihan bahan ajar sangatlah penting untuk memenuhi jenjang tingkat pembelajaran siswa yang dimulai dari tahap dasar dan secara bertahap ke tingkat yang lebih sulit tanpa menimbulkan kesulitan yang baru untuk siswa dalam mempelajari Bahasa Mandarin. Pemilihan bahan ajar yang tepat akan mampu mendorong siswa untuk lebih giat dalam mempelajari Bahasa Mandarin, tidak hanya dibutuhkan bahan ajar yang baik dan sesuai jenjang siswa tetapi juga dibutuhkan kemampuan guru dalam menyampaikan materi yang akan diberikan kepada siswa pembelajar.

Penulis berusaha untuk menjabarkan beberapa bahan ajar Bahasa Mandarin yang digunakan di Sekolah Menengah Umum berdasarkan pada kesesuaian materi serta tujuan pembelajaran serta jenjang siswa pembelajar. Apakah materi ajar dan kedalaman materi tersebut akan sesuai dengan jenjang siswa dan apakah materi tersebut sudah mampu memenuhi standar nasional untuk pengajaran Bahasa Mandarin di Sekolah Menengah Umum. Buku ajar di Sekolah Menengah Umum tiap-tiap sekolah tidaklah sama, karenanya untuk penulisan tahap pertama ini penulis hanya akan membahas 3 buku ajar yang paling banyak dipakai oleh guru yaitu: Kuaile Hanyu 快乐汉语, 跟我学汉语 (Learn Chinese with me), 汉语会话 301 句 (Conversational Chinese 301).

\section{PEMBAHASAN}

\section{Standardisasi Bahan Ajar Bahasa Mandarin Berdasarkan Badan Standar Nasional Pendidikan}

Tujuan pembelajaran Bahasa Mandarin adalah agar peserta didik mampu mengembangkan keterampilan dalam berkomunikasi lisan dan tulisan untuk memahami dan menyampaikan informasi, pikiran, dan perasaan. Untuk itu dibutuhkan standar kompetensi dasar yang harus dipenuhi dalam proses pembelajaran guna tercapainya tujuan pembelajaran Bahasa Mandarin. Kompetensi dasar ini meliputi empat kemampuan dasar berbahasa yaitu mendengar, berbicara, membaca dan menulis. (BSNP: 2009)

Dalam proses pembelajaran diharapkan pembelajar dapat memahami bacaan yang terdapat dalam bahan ajar, melalui bahan bacaan siswa mampu menyerap dan memahami budaya bangsa lain serta menghargai budaya bangsa sendiri. Dengan memahami budaya bangsa lain diharapkan kelak siswa akan mampu menggunakan dan mengaplikasikannya didalam bahasa yang dipelajari.

Agar siswa mampu memahami dan mengenal budaya melalui bahasa maka disusunlah sebuah standar nasional Bahasa Mandarin yang harus ada di dalam bahan ajar. Penyusunan bahan ajar ini berdasarkan tingkatan siswa yang dimulai dari termudah dan meningkat secara berjenjang. 
Pembelajaran Bahasa Mandarin di Sekolah Menengah Umum dianggap sebagai awal pembelajaran Bahasa Mandarin Dasar karena itu standar materi yang disusun disesuaikan sebagai dasar dari proses pembelajaran Bahasa Mandarin.

Badan Sertifikasi Nasional Pendidikan memberikan standar kompetensi dasar Bahasa Mandarin yang harus ada pada setiap bab buku ajar Bahasa Mandarin meliputi 4 kemampuan dasar berbahasa yaitu: mendengar, berbicara, membaca, dan menulis yang setiap jenjang tingkatan pembelajaran diharuskan mencakup materi yang sudah ditetapkan. Adapun materi yang diberikan dibedakan berdasarkan jenjang kebutuhan siswa pembelajar di sekolah terbagi menjadi dua bagian yaitu Pembelajaran Bahasa Mandarin untuk kelas Bahasa dan untuk kelas program pilihan. Pembelajaran Bahasa Mandarin untuk kelas program pilihan standar materi yang diberi sejak kelas X sedangkan untuk kelas Bahasa memiliki standar materi yang lebih mendalam ketika memasuki kelas XI.

Standar materi Bahasa Mandarin untuk kelas program pilihan terdiri dari: Kelas X semester 1 berisikan materi yang membahas mengenai Identitas Diri sedangkan pada semester 2 materi yang harus diberikan adalah mengenai Kehidupan Sekolah. Kelas XI semester 1 berisikan materi yang membahas mengenai Kehidupan Keluarga sedangkan pada semester 2 berisi materi mengenai Kehidupan Seharihari. Kelas XII semester 1 berisi tentang Kegemaran sedangkan pada semester 2 berisi materi mengenai Pekerjaan.

Standar materi Bahasa Mandarin untuk kelas program Bahasa; Kelas XI semester 1 berisikan materi yang membahas mengenai Identitas Diri dan Kehidupan Sekolah sedangkan pada semester 2 berisikan materi yang membahas mengenai Kehidupan Keluarga dan Kehidupan Sehari-hari. Kelas XII semester 1 materi yang dibahas mengenai Hobby dan Wisata, sedangkan pada semester 2 materi yang dibahas adalah mengenai Layanan Umum dan Transportasi. Materi pada kelas X dan kelas XI pada kelas Bahasa terdapat pengulangan materi, hal ini dikarenakan pada kelas bahasa materi kelas X diharapkan dapat dikuasai lebih baik sehingga dibutuhkan pengulangan. Karena sedikitnya sekolah yang menyelenggarakan kelas bahasa maka banyak guru yang tidak mengetahui bahwa pembelajaran Bahasa Mandarin pada program kelas pilihan dan kelas bahasa memiliki kedalaman materi yang berbeda.

\section{Analisis Buku Ajar Bahasa Mandarin yang digunakan di Sekolah Menengah Umum}

Pada 6 dan 7 Juli 2012 penulis berkesempatan mengikuti workshop bahan ajar yang diselenggarakan oleh UNJ, yang pada kesempatan itu dihadiri oleh 20 orang guru yang mengajar Bahasa Mandarin di Sekolah Menengah Umum. Dari dialog dan pembicaraan mengenai bahan ajar penulis mendapatkan banyak hal selain itu guru-guru yang diundang merupakan guru-guru Bahasa Mandarin yang sudah memiliki pengalaman dalam mengajar di Sekolah Menengah Umum.

Sekolah-sekolah memberi kebebasan kepada guru untuk memilih bahan ajar yang akan digunakan dalam pembelajaran Bahasa Mandarin, tetapi ada juga sekolah yang sudah menentukan buku ajar apa yang akan diberikan kepada siswa sehingga guru hanya mengikuti kebijakan sekolah tersebut. Terdapat juga guru yang berasal dari lembaga kursus tetapi mengajar di Sekolah Menengah Umum, karena sekolah tersebut bekerjasama dengan lembaga kursus tersebut untuk penyelenggaraan pembelajaran Bahasa Mandarin. Lembaga kursus tidak memilih buku ajar Bahasa Mandarin yang sudah tersedia dipasaran tetapi mereka membuat sendiri modul ajar yang akan diberikan kepada siswa.

Berdasarkan diskusi pada workshop tersebut penulis mengambil beberapa buku ajar yang lebih banyak digunakan disekolah-sekolah untuk ditelaah apakah buku ajar tersebut sesuai dengan standar kompetensi yang sudah ditetapkan. 


\section{Kuaile Hanyu 快乐汉语}

Kuaile Hanyu merupakan buku terbitan Beijing, Renmin Jiaoyu Chubanshe, buku ini menggunakan Bahasa Inggris sebagai bahasa pengantar. Buku ini terdiri dari 3 jilid buku dan diikuti dengan CD. Biasanya guru Sekolah Menengah Atas hanya menggunakan buku jilid 1 dimana materi didalam buku ini terbagi menjadi 8 unit yang tiap-tiap unitnya terdapat 3 pembahasan yang menjabarkan dari topik besar pada tiap unit.

Tabel 1 Materi yang terdapat dalam Buku Kuaile Hanyu

\begin{tabular}{ll}
\hline \multicolumn{1}{c}{ Unit 1 You and I 我和你 } & \multicolumn{1}{c}{ Unit 2 My Family 我的家 } \\
\hline 第一课 你好 & 第一课 爸爸、妈妈 \\
第二课 你叫什么 & 第二课 我有一只小猫 \\
第三课 你家在哪儿 & 第三课 我家不大
\end{tabular}

\begin{tabular}{ll}
\hline \multicolumn{1}{c}{ Unit 3 Food 饮食 } & \multicolumn{1}{c}{ Unit 4 School life 学校生活 } \\
\hline 第一课 喝牛奶, 不喝咖啡 & 第一课 中文课 \\
第二课 我要苹果, 你呢 & 第二课 我们班 \\
第三课 我喜欢海鲜 & 第三课 我去图书馆
\end{tabular}

\begin{tabular}{ll}
\hline \multicolumn{1}{c}{ Unit 5 Time and Weather 时间和天气 } & \multicolumn{1}{c}{ Unit 6 Job 工作 } \\
\hline 第一课 现在几电 & 第一课 他是医生 \\
第二课 我的生日 & 第二课 他在医院工作 \\
第三课 今天冷不冷 & 第三课 我想做演员
\end{tabular}

\begin{tabular}{ll}
\multicolumn{1}{c}{ Unit 7 Hobby 爱好 } & Unit 8 Transport and travel 交通和旅游 \\
\hline 第一课 你的爱好是什么 & 第一课 这是火车站 \\
第二课 你会打网球吗 & 第二课 我飞机去 \\
第三课 我天天看电视 & 第三课 汽车站在前边 \\
\hline
\end{tabular}

Unit 1 bertemakan You and I 我和你 di dalamnya terdapat materi 你好; 你叫什么; 你家在 哪儿。Ketiga materi ini merupakan materi dasar yang sering ada dalam buku ajar pembelajaran Bahasa Mandarin, merupakan materi menyapa, memperkenalkan diri dan menanyakan tempat tinggal. Keseluruhan materi ini merupakan bentuk pengenalan diri dan jika dilihat berdasarkan kompetensi dasar pembelajaran yang hendak dicapai dalam pembelajaran bahasa mandarin materi ini sudah sangat cocok untuk digunakan didalam kelas X dalam semester 1 .

Unit 2 bertemakan My Family 我的家 di dalamnya terdapat materi 爸爸、妈妈; 我有一只小 猫; 我家不大。Materi ini bercerita mengenai kedua orangtua, anggota keluarga dan juga kondisi keluarga. Dalam standar kompetensi yang ditetapkan seharusnya materi ini akan ada di kelas XI pada semester 1 bukan pada kelas X semester 1 .

Unit 3 bertemakan Food 饮食 didalamnya terdapat materi 喝牛奶, 不喝咖啡; 我要苹果, 你呢; 我喜欢海鲜。Materi yang terkandung didalam materi ini adalah berisikan mengenai minuman, buah-buahan serta makanan kegemaran. Materi ini masih dapat dikategorikan kepada bentuk pengenalan diri, yaitu kegemaran seseorang terhadap makanan yang disukai atau tidak sehingga masih dapat dikatakan bahwa materi ini masih masuk dalam standar untuk diajarkan pada kelas X di semester 1 . 
Unit 4 bertemakan School life 学校生活 di dalamnya terdapat materi 中文课; 我们班; 我去 图书馆。Materi ini berisikan mengenai pelajaran Bahasa Mandarin, keadaan kelas serta pergi ke perpustakaan yang merupakan tempat-tempat yang terdapat dilingkungan sekolah. Unit ini jika diberikan pada semester 2 pada kelas X maka sudah sangat sesuai dengan standar materi yang hendak dicapai pada kelas $\mathrm{X}$ yang membahas kehidupan sekolah.

Unit 5 bertemakan Time and Weather 时间和天气 di dalamnya terdapat materi 现在机电; 我 的生日; 今天冷不冷。Pembagian materi di dalam unit ini terdiri dari menanyakan waktu, tanggal kelahiran serta cuaca. 2 materi awal dapat dikategorikan kedalam identitas diri dan juga kehidupan sekolah, tetapi untuk materi ketiga yaitu cuaca dapat digolongkan didalam materi mengenai kehidupan sehari-hari. Sehingga materi 1 dan 2 jika diberikan pada kelas X semester 1 dan 2 masih sesuai dengan tujuan pembelajaran Bahasa Mandarin. Tetapi untuk materi ke 3, yaitu cuaca yang masuk kategori kehidupan sehari-hari jika melihat dari standar kompetensi yang akan dituju maka materi ini lebih tepat untuk masuk kedalam materi kelas XI semester 2.

Unit 6 Job 工作 materi yang berisikan 他是医生; 他在医院工作; 我想做演员。Materi ini membahas mengenai pekerjaan, tempat bekerja serta cita-cita. Pada pembahasan materi pekerjaan dan tempat kerja serta cita-cita dapat dikategorikan sebagai pekerjaan yang di dalam standar kompetensi yang hendak dicapai terdapat pada kelas XII semester terakhir atau semester 2. Jika materi ini diberikan pada kelas XI semester 2, materi ini tidak sesuai dengan standar kompetensi yang ingin dicapai dalam proses pembelajaran.

Unit 7 Hobby 爱好 terdiri dari beberapa materi yaitu 你的爱好是什么; 你会打网球吗; 我 天天看电视。Materi ini membahas mengenai hobi, kegemaran terhadap olahraga dan kegemaran terhadap menonton tv. Ketiga materi ini masuk dalam kategori hobi dan terdapat dalam kompetensi dasar yang harus dicapai dalam kelas XII semester 1 pada kelas program Bahasa. Jika diberikan pada kelas program khusus pada jenjang kelas XII maka materi ini tidak sesuai dengan standar materi yang harus dicapai.

Unit 8 Transportasi and Travel 交通和旅游 terdiri dari beberapa materi ajar yaitu 这是火车站; 我坐飞机去; 汽车站在前边。Materi ini membahas mengenai stasiun kereta api, kendaraan yang akan digunakan menuju ke suatu tempat serta letak stasiun bus. Ketiga materi ini dapat digolongkan kepada materi mengenai transportasi dimana materi ini berada pada jenjang kelas XII semester 2 pada kelas program Bahasa, jika materi ini diberikan kepada kelas program khusus maka materi ini tidak cocok karena untuk jenjang kelas XII tidak terdapat materi mengenai transportasi.

Guru Sekolah Menengah Umum hanya memakai buku jilid 1 dalam mengajar Bahasa Mandarin baik di kelas X, XI, maupun kelas XII karena beberapa materi yang terdapat dalam buku ini sudah merupakan standar materi yang harus ada di dalam kelas X, XI dan XII. Materi ajar yang terdapat dalam buku Kuaile Hanyu dalam beberapa materi ada yang terdapat dalam standar kompetensi dasar yang hendak dicapai dalam sistem pengajaran Bahasa Mandarin baik untuk jenjang program kelas khusus maupun kelas Bahasa. Materi-materi yang cocok untuk kelas program khusus adalah materi 我和你; 我的家; 饮食; 学校生活; 时间和天气; 工作; 爱好。Sedangkan untuk materi 交通和旅游 tidak cocok untuk siswa program kelas khusus, karena materi ini seharusnya berada pada program kelas Bahasa pada kelas XII semester 2. Tetapi jika buku ini hendak dipakai sebagai buku pegangan pada kelas XII kelas Bahasa, berdasarkan tema buku ini masih masuk dalam kategori mencapai standar yang diinginkan. 


\section{跟我学汉语 (Learn Chinese with Me)}

Learn Chinese with Me merupakan buku terbitan Beijing, Renmin Jiaoyu Chubanshe. Buku ini terdiri dari beberapa bahasa sebagai bahasa pengantar seperti: Bahasa Inggris, Bahasa Korea, Bahasa Indonesia, Bahasa Jepang, dll. Biasanya guru di Sekolah Menengah Umum menggunakan buku yang berpengantar Bahasa Inggris, tetapi ada juga sekolah yang menggunakan Bahasa Indonesia. Buku ini terdiri dari 3 jilid buku dan diikuti dengan CD. Pada buku jilid 1 materi terbagi menjadi 6 unit besar atau 6 pokok topik utama yang tiap-tiap unitnya terdapat 6 pembahasan yang menjabarkan dari topik besar pada tiap unit.

Tabel 2 Materi yang terdapat dalam Buku Learn Chinese with Me

\begin{tabular}{ll}
\hline \multicolumn{1}{c}{ Unit 1 School, Classmates and teacher } & Unit 2 Hanging out with my friends \\
\hline 第一课 你好 & 第一课 他是谁 \\
第二课 再见 & 第二课 谁是你的好朋友 \\
第三课 我是王家明 & 第三课 你有几张中文光盘 \\
第四课 谢谢 & 第四课 这是谁的钱包 \\
第五课 他们是学生吗 & 第五课 祝你生日快乐 \\
第六课 他们是我的朋友 & 第六课 今天我很高兴
\end{tabular}

\begin{tabular}{ll}
\hline \multicolumn{1}{c}{ Unit 3 My Family and I } & Unit 4 Four Seasons of the year \\
\hline 第一课 你多大 & 第一课 现在几点 \\
第二课 这是我的狗 & 第二课 你每天几点起床 \\
第三课 你从哪里来 & 第三课 昨天、今天、明天 \\
第四课 我住在柏树街 & 第四课 星期六你干什么 \\
第五课 你家有几口人 & 第五课 今天气怎么样 \\
第六课 我爸爸是医生 & 第六课 冬天冷, 夏天热 \\
\hline \multicolumn{1}{c|}{ Unit 5 Food and Clothing } & \\
\hline 第一课 我要二十个饺子 & Unit 6 Sports and health \\
第二课 你们家买不买年货 & 第一课 你哪儿不舒服 \\
第三课 一共多少钱 & 第二课 医生, 我牙疼 \\
第四课 你喜欢什么颜色 & 第三课 你会游泳吗 \\
第五课 穿这件还是穿那件 & 第四课 去游泳池怎么走 \\
第六课 他什么样子 & 第五课 你去哪儿度署假 \\
& 第六课 运动场上有很多人 \\
\hline
\end{tabular}

Unit 1 School, Classmates and Teacher, di dalam topik besar bertema ini terdapat 6 topik kecil yang terbagi didalam tiap pelajaran. Keenam topik kecil ini terdiri dari 你好; 再见; 我是王家明; 谢谢; 他们是学生吗; 他们是我的朋友。Tema 你好; 再见; 我是王家明 dan 谢谢 dapat dikategorikan dalam tema identitas diri yang terdapat dalam kelas $\mathrm{X}$ pada semester 1 proses pembelajaran Bahasa Mandarin yang harus ada didalam kurikulum pembelajaran. Sedangkan topik 他 们是学生吗 dan 他们是我的朋友 dapat dikategorikan pada tema kehidupan sekolah yang harus diberikan pada kelas $\mathrm{X}$ semester 2 . Keenam topik ini dapat dikategorikan sebagai topik utama yang harus terpenuhi di dalam standar pembelajaran bahasa Mandarin untuk kelas X yang sudah ditetapkan oleh BSNP.

Unit 2 Hanging out with my friends, di dalam topik besar bertema ini terdapat topik-topik kecil yaitu: 他是谁, 谁是你的好朋友, 你有几张中文光盘, 这是谁的钱包, 祝你生日快乐, 今天我 很高兴。Dari keenam topik kecil ini, dua di antaranya dapat dikategorikan sebagai kehidupan sekolah 
yaitu 他是谁; 谁是你的好朋友, sedangkan untuk tema 你有几张中文光盘; 这是谁的钱包; 祝你 生日快乐; 今天我很高兴 dengan tema-tema ini berada pada kategori tema kehidupan sehari-hari yang di dalam starndar proses pembelajaran diberikan pada kelas XI semester 2 pada kelas program pilihan. Jika dikategorikan pada kelas program bahasa, dua topik awal dari unit ini masuk dalam proses pembelajaran kelas XI semester 1. Sedangkan pada empat topik terakhir masuk dalam semester 2.

Unit 3 My Family and I, terdiri dari 你多大; 这是我的狗; 你从哪里来; 我住在柏树街; 你家有几口人; 我爸爸是医生 dalam keenam topik kecil ini topik 你多大; 这是我的狗; 你从哪里 来 dapat dikelompokkan dalam kehidupan sehari-hari sedangkan topik 我住在柏树街; 你家有几口 人 dapat dikategorikan kedalam kehidupan keluarga. Dimana pada tiga bab awal yang terdapat dalam unit ini merupakan topik yang harus ada dalam proses pembelajaran di kelas XI semester 2 sedangkan 2 topik berikut merupakan topik yang harus ada di semester 1 pada kelas XI. Sedangkan untuk kelas program bahasa tiga topik awal ini merupakan topik yang harus ada didalam kelas XI semester 1 dan dua topik berikut harus ada di kelas XI semester 2. Sedangkan untuk topik 我爸爸是医生 merupakan topik pekerjaan yang akan muncul pada kelas XII semester 2 pada program kelas khusus.

Unit 4 Four Seasons of the year, terdiri dari 现在几点; 你每天几点起床; 昨天、今天、明 天; 星期六你干什么; 今天天气怎么样; 冬天冷, 夏天热 empat topik awal yaitu 现在几点; 你 每天几点起床; 昨天、今天、明天；星期六你干什么 dapat dikategorikan kepada topik kehidupan sehari-hari yang terdapat dalam topik kelas XI semester 2 pada program kelas khusus dan merupakan materi yang harus terdapat pada kelas XI semester 1 pada program kelas bahasa. Sedangkan untuk topik 今天天气怎么样; 冬天冷, 夏天热 dalam topik besar yang telah ditetapkan oleh BSNP tidak terdapat materi mengenai cuaca. Ini karena iklim atau cuaca Indonesia yang hanya memiliki dua musim sedangkan pada buku-buku terbitan China biasanya membicarakan 4 musim yang memang terdapat di negara China. Perbedaan iklim ini sering kali membingungkan bagi siswa yang sama sekali tidak pernah mengalami musim berbeda selain kemarau dan penghujan. Karenanya, dua topik terakhir ini tidak cocok dalam kategori BSNP.

Unit 5 Food and Clothing terdiri dari 我要二十个饺子; 你们家买不买年货; 一共多少钱; 你喜欢什么颜色; 穿这件还是穿那件; 他什么样子. Keenam topik kecil ini dapat dikategorikan kepada kehidupan sehari-hari yang terdapat dalam materi kelas XI semester 2 program kelas khusus dan pada kelas XI semester 1 pada program kelas bahasa. Tidak hanya dikategorikan kepada tema kehidupan sehari-hari tetapi juga dapat digolongkan kepada materi kegemaran atau hobi yang terdapat pada materi kelas XII semester 1 baik di program kelas khusus maupun kelas bahasa.

Unit 6 Sports and health terdiri dari 你哪儿不舒服; 医生, 我牙疼; 你会游泳吗; 去游泳 池怎么走; 你去哪儿度暑假; 运动场上有很多人 dua topik awal yaitu 你哪儿不舒服 dan 医生, 我牙疼 dapat dikategorikan sebagai topik layanan umum yang terdapat pada program kelas bahasa yang diberikan pada kelas XII semester 2. Sedangkan untuk topik 你会游泳吗; 去游泳池怎么走; 你去哪儿度暑假; 运动场上有很多人 dapat dikategorikan pada hobi dan wisata yang terdapat pada materi kelas XII semester 1 program kelas bahasa, tidak hanya kelas program bahasa tetapi juga dapat digolongkan pada materi kelas XII semester 1 pada program kelas khusus tentang kegemaran.

Keenam tema besar yang terdapat dalam buku 跟我学汉语 (Learn Chinese with Me) sudah dapat dikatakan memenuhi standar kompetensi materi ajar yang sudah ditetapkan oleh BSNP. Namun perlu menjadi perhatian bagi guru yang mengajar dan menggunakan buku ini karena beberapa urutan topik materi yang tidak sesuai dengan jenjang kelas. Sehingga ketika mengajar, sebaiknya guru terlebih dulu membuat sebuah modul pembelajaran dan tidak harus memberikan materi pembelajaran secara berurutan. Akan tetapi, disesuaikan dengan tema besar yang harus dicapai siswa dalam tiap jenjang pembelajaran. 


\section{汉语会话 301 句 (Conversational Chinese 301)}

汉语会话 301 句 (Conversational Chinese 301) merupakan buku terbitan Beijing, Beijing yuyan daxue chubanshe. Buku ini terdiri dari dua jilid yaitu buku 1 dan buku 2 serta dilengkapi dengan buku latihan yang diberikan secara terpisah. Biasanya guru di Sekolah Menengah Umum menggunakan buku 1 untuk mengajar di seluruh jenjang pembelajaran di Sekolah Menengah Umum. Buku ini mengelompokkan materi berdasarkan tema besar yang akan dibahas pada topik-topik kecil yang jumlah topiknya tidak sama dalam tiap tema besar.

Tabel 3 Materi yang terdapat dalam buku Learn Chinese with Me

\begin{tabular}{ll}
\hline \multicolumn{1}{c}{ 问候 Greetings } & 相识 Making an Acquaintance \\
\hline 第一课 你好 & 第四课 您贵姓 \\
第二课 你身体好吗 & 第五课 我介绍一下儿 \\
第三课 你工作忙吗 &
\end{tabular}

\begin{tabular}{ll}
\hline \multicolumn{1}{c}{ 询问 Making an Inquiry } & \multicolumn{1}{c}{ 需要 Needs } \\
\hline 第六课 你的生日是几月几号 & 第十一课 我要买橘子 \\
第七课 你家有几口人 & 第十二课 我想买衣 \\
第八课 现在几点 & 第十三课 要换车 \\
第九课 你住在哪儿 & 第十四课 我要去换钱 \\
第十课 邮局在哪儿 & 第十五课 我要照张相
\end{tabular}

\begin{tabular}{cc}
\hline 相约 Making an Appointment & 迎接 Welcome \\
\hline $\begin{array}{c}\text { 第十六课 你看过京剧吗 } \\
\text { 第十七课 去动物园 }\end{array}$ & $\begin{array}{c}\text { 第十八课路上辛苦了 } \\
\text { 第十九课 欢迎你 }\end{array}$ \\
\hline 招待 Reception \\
\hline 第二十课为我们的友谊干杯 \\
\hline
\end{tabular}

问候 Greetings merupakan topik besar pertama yang dijumpai pada buku Conversation Chinese 301. Dalam topik ini dibagi menjadi tiga pelajaran yang masing-masing temanya adalah 你好; 你身体好吗; 你工作忙吗. Ketiga tema ini jika disesuaikan dengan standar kompetensi BSNP, masuk dalam kategori identitas diri yang terdapat dalam pembelajaran kelas X semester 1.

相识 Making an Acquaintance merupakan topik besar kedua yang terdiri dari dua pelajaran yang berjudul 您贵姓 dan 我介绍一下儿. Kedua tema ini masih masuk dalam tema besar identitas diri yang diberikan pada proses pembelajaran kelas X semester 1 .

询问 Making an Inquiry merupakan tema besar ketiga yang terdiri dari lima bab yang terdiri dari tema-tema berikut: 你的生日是几月几号; 你家有几口人; 你住在哪儿; 邮局在哪儿. Pada tema 你的生日是几月几号 dapat dikategorikan pada tema identitas diri yang terdapat pada kelas $\mathrm{X}$ semester 1 sedangkan untuk tema 你家有几口人 dan 你住在哪儿 dapat dikategorikan kepada materi kehidupan keluarga yang terdapat pada materi kelas XI semester 1 pada kelas program khusus sedangkan pada kelas program bahasa materi ini muncul pada kelas XI semester 2. Bab berikutnya dengan tema 邮局在哪儿; 现在几点 dapat dikategorikan pada kehidupan sehari-hari yang terdapat dalam materi utama kelas XI semester 2 pada kelas program khusus dan juga program bahasa. 
需要 Needs tema besar keempat yang terdapat pada buku Conversation Chinese 301, tema ini terbagi menjadi lima topik kecil yaitu: 我要买橘子; 我想买毛衣; 要换车; 我要去换钱; 我要照 张相. Tema 我要买橘子 dan 我想买毛衣 dapat dikategorikan dalam materi kehidupan sehari-hari yang terdapat dalam materi kelas XI semester 2 kelas program khusus dan kelas program bahasa. Sedangkan pada tema 要换车 merupakan topik materi pada kelas program bahasa kelas XII semester 2 yaitu transportasi. Sedangkan untuk kelas program khusus materi ini tidak terdapat dalam proses pembelajaran yang harus mereka capai. 我要去换钱 merupakan topik dari materi layanan umum yang terdapat pada kelas XII kelas program bahasa dan seperti halnya tema transportasi tema inipun tidak ada di kelas program khusus. 我要照张相 topik ini dapat dikategorikan kepada kegemaran pada kelas XII semester 1 kelas program khusus dan juga kelas program bahasa.

相约 Making an Appointment merupakan topik besar kelima yang di dalamnya terdapat topik 你看过京剧吗; 去动物园. Kedua tema kecil ini termasuk dalam tema kegemaran pada kelas XII semester 1 kelas program khusus dan topik hobi dan wisata pada kelas XII semester 1 kelas program bahasa.

迎接 Welcome berisikan dua topik kecil yaitu 路上辛苦了 dan 欢迎你. Kedua topik kecil ini merupakan turunan dari tema layanan umum dan transportasi yang terdapat dalam tema yang harus ada pada kelas XII semester 2 kelas program bahasa sedangkan pada kelas program khusus tema ini tidak ada.

招待 Reception merupakan tema besar terakhir yang terdapat dalam buku Conversation Chinese 301 berisi satu topik kecil yang berjudul 为我们的友谊干杯. Tema ini tidak memiliki kelompok tema yang pasti tetapi tema ini dapat juga digolongkan sebagai tema kehidupan sehari-hari yang terdapat pada tema kelas XI semester 2 baik pada kelas program khusus maupun program bahasa.

Kedalaman materi yang terdapat dalam buku Conversation Chinese 301 cukup baik untuk jenjang Sekolah Menengah Umum, tetapi buku ini lebih banyak bercerita tentang kehidupan siswa asing di China. Sedangkan hal ini untuk siswa lokal sangatlah sulit dipahami, seperti misalnya pada materi 要换车, dengan lokasi yang disebutkan adalah lokasi di China. Bagi siswa lokal, hal ini sangatlah sulit dipahami. Guru dalam memberikan materi juga sebaiknya menyesuaikan tema besar yang akan dicapai dalam jenjang kelas pembelajaran.

\section{SIMPULAN}

Dalam pembelajaran bahasa Mandarin sebaiknya guru mampu memilah materi ajar yang cocok diberikan kepada siswa agar proses pembelajaran yang ingin dicapai dapat terpenuhi dan bukan membebani siswa dalam memahami pembelajaran tersebut.

Meskipun ketiga buku yang sudah dibahas memenuhi standar yang diharapkan tercapai pada jenjang pembelajaran Bahasa Mandarin pada Sekolah Menengah Umum, perlu diberi catatan bahwa materi untuk kelas $\mathrm{X}$ semester 1 dan 2 pada kelas program bahasa materi ini akan muncul kembali pada kelas XI semester 1 . Kedua materi ini digabungkan menjadi materi yang harus terdapat dalam pembelajaran semester 1 , tetapi tentu saja kedalaman materi pada kelas ini lebih jika dibandingkan dengan tema materi pada kelas X semester 1 dan 2.

Masih banyak guru yang tidak tahu bahwa materi ajar yang harus diberikan pada kelas program pilihan dan program bahasa berbeda. Sehingga ketika guru tersebut menggunakan buku yang diperuntukkan untuk kelas bahasa, tetapi diberikan kepada kelas khusus, mereka merasa kesulitan 
untuk mentransfer ilmu. Hal itu disebabkan tidak hanya karena materi pada kelas bahasa lebih dalam, tetapi juga karena durasi jam pada kelas bahasa lebih banyak dari kelas program khusus. Dengan demikian, materi yang disampaikan tidak mencapai standar kompetensi yang ingin dicapai.

\section{DAFTAR PUSTAKA}

Bo, L. (2006). Duiwai Hanyu Jiaoxue Lilun Yanjiu. Beijing: Beijing Shangwu Yinshuguan.

Fu, C.(2004). Gen Wo Xue Hanyu (Learn Chinese with me). Beijing: Renmin Jiaoyu Chubanshe.

Hesheng, Z. (2006). Duiwai Hanyu Jiaoshi Suzhi yu Jiaoshi Peixun Yanjiu. Beijing: Beijing Shangwu Yinshuguan.

Houde, C. (2001). Jichu Jiaoyu Xin Gainian Youxiao Jiaoxue. Beijing: Beijing jiaoyu kexue chuban she.

Shaoqi, L. (2004). Kuaile Hanyu. Beijing: Renmin Jiaoyu Chubanshe.

Standar kompetensi dan kompetensi dasar SMU Badan Standar Nasional Pendidikan, 2006

Xun, L. (2006). Hanyu Zuowei Di er Yuyan Jiaoxue Qianlun. Beijing: Beijing Yuyan Daxue Chubanshe.

Yonghua, C. (2005). Hanyu Ketang Jiaoxue Jiqiao. Beijing: Beijing Yuyan Daxue Chubanshe.

Yuhua, K. (2004). Hanyu Huihua 301 Ju (Conversational Chinese 301). Beijing: Beijing yuyan daxue chubanshe. 